\title{
Flow injection visible diffuse reflectance quantitative analysis of total sulfur in biodiesel, in plant leaves and in natural waters
}

\author{
Matthieu Tubino*, Carlos A.R. Queiroz \\ Institute of Chemistry, State University of Campinas \\ CP 6154, CEP 13083-970 Campinas, SP, Brazil
}

\begin{abstract}
Flow injection (FI) methodology, using diffuse reflectance in the visible region of the spectrum, for the analysis of total sulfur in the form of sulfate, precipitated in the form of barium sulfate, is presented. The method was applied to biodiesel, to plant leaves and to natural waters analysis. The analytical signal $(\boldsymbol{S})$ correlates linearly with sulfate concentration $(\boldsymbol{C})$ between 20 and $120 \mathrm{ppm}$, through the equation $\boldsymbol{S}=1.138+0.0934 \mathbf{C}(\mathrm{r}=0.9993)$. The experimentally observed limit of detection is about 10 ppm. The mean R.S.D. is about $3.0 \%$. Real samples containing sulfate were analyzed and the results obtained by the FI and by the reference batch turbidimetric method using the statistical Student's $t$-test and F-test were compared.
\end{abstract}

Keywords: diffuse reflectance; solution; sulfur; sulfate; biodiesel; plant leaves; water

\section{Introduction}

When compared, for example, with those methods that use transmittance (absorbance), reflectance quantitative analytical methods in the UV-Vis region are not very popular. This fact can be attributed, in part, to the difficulty in preparing rigorously homogeneous reflecting surfaces. However, despite this problem, several quantitative reflectometric methods for the determination of analytes immobilized on solid supports have been developed offering quite good results [1-10]. It is also possible to work in solution, measuring the diffuse reflectance of solids suspended in liquids $[1-2,8]$.

Turbidimetry and nephelometry are closely related analytical techniques based on the scattering of radiation by a solution containing dispersed particulate matter. When a radiation passes through a transparent medium in which solid particles are dispersed, part of the radiation is scattered in all directions, giving a turbid appearance to the mixture. Turbidimetry is based on the mea- suring of the intensity of the radiation transmitted by the solution whereas nephelometry is based on the scattered radiation at an angle, usually at the right angle. Turbidimetry is usually applied in the cases of concentrated particulates dispersed in solution whereas nephelometry is based on the scattered radiation at an angle, usually at the right angle. Turbidimetry is usually applied in the cases of concentrated particulates dispersed in solution while nephelometry offers reliable results at low concentrations because a small scattering intensity against a black background is easier to measure than a small change in intensity of intense transmitted radiation. The intensity of radiation appearing at any angle depends upon the number of particles, their size and shape, as well as the wavelength of the radiation [11].

If the light reflected out of the plane of incidence of the radiation is considered the phenomenon it can be considered as diffuse reflectance [1-2,8], to which Kubelka-Munk theory can be applied [12]. 
The application of flow methods based on the formation of precipitates in line implies in some possible problems. Among them the most obvious are the clogging of the tubes and the deposition of precipitate on the windows of the optical cell.

Despite these problems however various turbidimetric, nephelometric, and reflectometric methods were reported in the literature [10 - 24].

Recently, the possibility to determine nickel by diffuse reflectance in a flow system where it was precipitated and kept dispersed as nickel dimethylglyoximate, a solid compound that easily adders to surfaces and that rapidly forms agglomerates was demonstrated [1].

Sulfate is probably the most popular analyte determined by flow turbidimetric procedure, based on its precipitation as barium sulfate. Krug et al., in 1977 [25] adapted to a flow injection procedure the classical batch turbidimetric method for the determination of sulfate in natural waters and plants digest. It has been successfully applied to a variety of matrixes as environmental, plant digests, clinical and wine samples [24-48]. Alternatively, flow procedures for sulfate analysis are based on the precipitation of $\mathrm{PbSO}_{4}$ [49]. A nephelometric flow method for sulfate was also described [50].

The nucleation of barium sulfate is $\mathrm{pH}$ dependent $[27,31,46]$. The $\mathrm{pH}$ not only affects the formation of the barium sulfate precipitate but also its structure. A precipitate obtained in a solution which $\mathrm{pH}$ is below 3 consists of well-shaped crystals, whereas at $\mathrm{pH}$ from 3 to 7 the precipitate is amorphous [27]. To obtain an acidic medium, hydrochloric acid is frequently applied. This addition is also done to prevent the formation of precipitates like carbonate, sulfite and phosphate of barium, which may interfere [48].

One of the critical problems in sulfate determination using its precipitation with barium ions is the formation of deposits of barium sulfate in the system, including on the cell windows. To resolve this situation, Liu and Dasgupta [40] proposed an elegant method where the precipitate is formed in situ in a drop. However, despite the fact that this system solved the problem of the deposition on the cell windows, the precipitation of barium sulfate in the capillary tubes of the flow system probably still remains.

In this work the objective was to develop a very simple reflectometric method for the determination of sulfate in natural water and in digests in which the deposition of barium sulfate into the flow system is minimized. In this sense, a simple glass cell without corners was idealized (essentially a glass tube) and a very thin precipitate was desired.

\section{Experimental}

\section{Apparatus}

Peristaltic pump: Model mp13 GJ4, Ismatec, Switzerland. Chart recorder: Cole Parmer 8375 Series (20 mV full scale), USA. Wheatstone bridge circuit: Leeds \& Northrup, Philadelphia, PA, USA. Pumping tubes: Tygon ${ }^{\circledR}$ R3607 (Ismatec, Switzerland); i.d. $0.51 \mathrm{~mm}$, o.d. $2.33 \mathrm{~mm}$, color code red-red; carrier; i.d. 1.14 mm, o.d. 2.86 $\mathrm{mm}$, color code red-red; sampling; i.d. $1.75 \mathrm{~mm}$, o.d. $3.47 \mathrm{~mm}$. Connecting tubes: Polyethylene (i.d. $0.9 \mathrm{~mm}$, o.d. $1.9 \mathrm{~mm}$ ). Reflectometric cell: It is similar to that already described [1] with the difference that it was constructed in black PTFE (polytetrafluoroethylene). Sample injector: This has been described previously in details [51]. This injector was constructed in polytetrafluoroethylene (PTFE) and consists essentially of three round pieces tightly connected through their centers by a screw. Holes of about $1.8 \mathrm{~mm}$ in diameter are paths for the solutions and also the connections for the polyethylene tubes that conduct these solutions to and from the valve. The two external pieces are fixed on a metallic base and the third (on which the sampling loop of constant volume is placed) is located between the other two as a sandwich. This central piece can be moved in a teeter movement around its axis. This movement allows the introduction of the sample into the flow system [51-53]. Glass cuvettes: For the batch procedure a $2 \mathrm{~cm}$ optical pathway glass cuvette was used. For the FI proposed method an $1 \mathrm{~cm}$ pathway glass flow cuvette was used. Spectrophotometer: For 
the batch procedure a Micronal model B-382 was used. Mixer with magnetic stirring: already described [54-55].

In Figure 1 a scheme of the flow injection system is shown. $\mathbf{A}_{\mathbf{1}}$ is the flow containing barium ions $0.050 \mathrm{~mol} \mathrm{~L}^{-1}$ with polyvinyl alcohol $0.05 \%$ $\mathrm{m} / \mathrm{v}$ in $\mathrm{HCl} 0.01 \mathrm{~mol} \mathrm{~L}^{-1}$. The flow $\mathbf{A}_{2}$ (carrier) is an $\mathrm{HCl} 0.01 \mathrm{~mol} \mathrm{~L}^{-1}$ aqueous solution. In this stream the sample containing sulfate is introduced. In the mixer $\mathbf{M}$ and in the coil $\mathbf{L}$ the reaction (precipitation) that is detected by the reflectometric sensor occurs. After five determinations it is recom- mendable to clean the line injecting $1 \mathrm{~mL}$ of an EDTA $0.02 \mathrm{~mol} \mathrm{~L}^{-1}$ in $\mathrm{NaOH} 0.6 \mathrm{~mol} \mathrm{~L}^{-1}$ solution [27,31], using a hypodermic syringe $\mathbf{S}$, in order to avoid accumulation of the precipitate along the line, including on the cell windows. In the mixer $\mathbf{M}$ the mixture of the reagent with the analyte solution is vigorously stirred, increasing the contact of the reagent species and therefore decreasing the reaction time. It is also expected that this stirring favors the formation of very small particles.

\section{FIGURE 1}

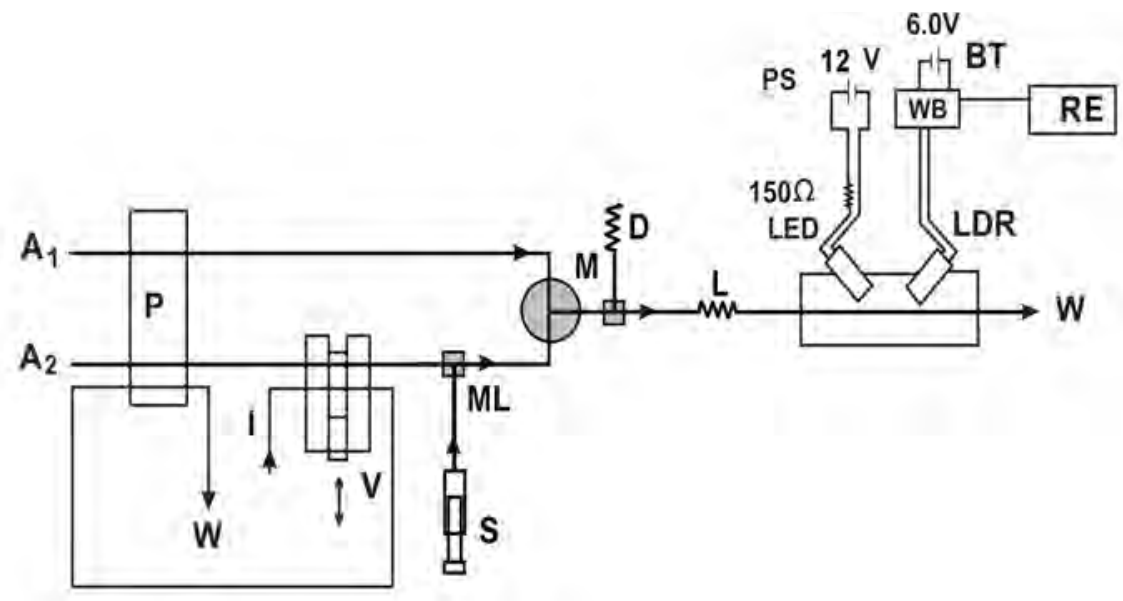

Figure 1. Scheme of the flow injection manifold: $\boldsymbol{A}_{1}=$ reagent solution of $\mathrm{Ba}^{2+} 0.050 \mathrm{~mol} \mathrm{~L} \mathrm{~L}^{-1}$ with polyvinyl alcohol $0.05 \% \mathrm{~m} / \mathrm{v}$ in $\mathrm{HCl} 0.01 \mathrm{~mol} \mathrm{~L} \mathrm{~L}^{-1}$ at a flow rate of $2.27 \mathrm{~mL} \mathrm{~min}^{-1} ; \boldsymbol{A}_{2}=\mathrm{HCl} 0.01 \mathrm{~mol} \mathrm{~L}{ }^{-1}$ at a flow rate of $2.27 \mathrm{~mL} \mathrm{~min}^{-1}$ (carrier solution); $\boldsymbol{D}=$ pulsation damper; $\boldsymbol{L}=100 \mathrm{~cm}$ length reaction coil; $\boldsymbol{M}=$ mixer with magnetic stirring; $\boldsymbol{M L}=$ introducing of EDTA cleaning solution; $\boldsymbol{S}=$ syringe with EDTA solution; $\boldsymbol{P}$ = peristaltic bomb; $\boldsymbol{I}=$ entrance of the aliquot one; $\boldsymbol{V}=$ sample introducing valve; $\boldsymbol{W}=$ waste; $\boldsymbol{B T}=6 \mathrm{~V}$ battery; $\boldsymbol{P S}=12.0$ V power supply; $\mathbf{W B}=$ Wheatstone bridge; $\boldsymbol{R E}=$ potentiometric chart recorder; $\mathbf{L E D}=$ light emitter diode; $\mathbf{L D R}=$ light dependent resistance; $\mathbf{I}=$ sampling inlet, volume of the aliquot $500 \mu \mathrm{L}$.

\section{Reagents and solutions}

All the reagents used were of analytical grade. The water was distilled in a glass distiller and deionized in a Milli-Q Plus Ultra-Pure system. $1.0 \mathrm{~L}$ of sulfate $1000 \mathrm{ppm}$ stock solution was prepared: $1.3760 \mathrm{~g}$ of the $\left(\mathrm{NH}_{4}\right)_{2} \mathrm{SO}_{4}$ dried in an oven for 2 hours at $120^{\circ} \mathrm{C}$ was dissolved in 1000.0 $\mathrm{mL}$ of water in a volumetric flask. The concentrations of the analyte used for the construction of the calibration curve were obtained from this stock solution after adequate dilutions.
Barium ions solution $0.050 \mathrm{~mol} \mathrm{~L}^{-1}$, with polyvinyl alcohol $0.05 \% \mathrm{~m} / \mathrm{v}$ in $\mathrm{HCl} 0.01 \mathrm{~mol} \mathrm{~L}^{-1}$, was prepared by dissolving $0.500 \mathrm{~g}$ of polyvinyl alcohol in $100 \mathrm{~mL}$ of boiling water, under agitation with a magnetic bar. This solution was transferred to a beaker containing $800 \mathrm{~mL}$ of water. When the resulting solution was clear $12.212 \mathrm{~g}$ of $\mathrm{BaCl}_{2} \cdot 2 \mathrm{H}_{2} \mathrm{O}$ were added. This last solution was cooled to ambient temperature and then $0.8 \mathrm{~mL}$ of concentrated $\mathrm{HCl}$ was added. The volume of the final solution was completed to $1000.0 \mathrm{~L}$ in a volumetric flask. The carrier solution, $\mathrm{HCl} 0.01$ 
mol L ${ }^{-1}$, was prepared by diluting $0.8 \mathrm{~mL}$ of concentrated $\mathrm{HCl}$ in 1 liter of water.

\section{Reference method}

As reference method the batch turbidimetric procedure was used [56-57]. The construction of the calibration curve was done as follows. Using a class A glass pipette, $2.0 \mathrm{~mL}$ of the barium $0.050 \mathrm{~mol} \mathrm{~L}^{-1}$ solution was put in a small $25 \mathrm{~mL}$ beaker containing a magnetic bar. $2.0 \mathrm{~mL}$ of the sulfate solution (in presence of PVA (0.05 $\% \mathrm{w} / \mathrm{v})$ and HCL (0.01 mol L $\left.{ }^{-1}\right)$ ) was carefully added under magnetic agitation. The system was allowed to react during 2 minutes with stirring. In sequence, the turbidimetric measurement was done in the spectrophotometer at $420 \mathrm{~nm}$, using a $2 \mathrm{~cm}$ pathway glass cell. The standard sulfate solutions were prepared in the following concentrations: 20, 40, 60, 80, 100 and 120 ppm (w/v). The calibration curve is described by the equation $\mathbf{A}=0.0879+0.01122 \mathbf{C}(\mathrm{r}=0.998)$, where $\mathbf{A}$ is the absorbance value and $\mathbf{C}$ the sulfate concentration in $\mathrm{mg} \mathrm{L}^{-1}$.

\section{Real samples}

Natural waters: In the case of natural waters I and II, an initial volume of the original samples was evaporated in order to concentrate the sulfate. $10 \mathrm{~mL}$ of $\mathrm{HCl} 0.1 \mathrm{~mol} \mathrm{~L}{ }^{1}$ per liter of water before the concentration process was added to avoid precipitation of carbonates. Natural water III was analyzed as it was in the bottle after degasified using ultrasound. Plant leaves: Adequate mass of soy leaves was carefully calcinated in a microwave furnace. The temperature was increased from the ambient to $100{ }^{\circ} \mathrm{C}$ and then in steps of $100{ }^{\circ} \mathrm{C}$ until $400{ }^{\circ} \mathrm{C}$, following a direct heating to $550{ }^{\circ} \mathrm{C}$. In the intermediate temperatures the sample stands during 30 minutes and at $550{ }^{\circ} \mathrm{C}$ during one hour. The residue was treated with water and with sodium carbonate during 30 minutes at about $80{ }^{\circ} \mathrm{C}$, following filtration directly in a $25.0 \mathrm{~mL}$ volumetric flask. Enough $\mathrm{HCl}$ solution $0.1 \mathrm{~mol} \mathrm{~L}^{-1}$ was drop-wise added until a $\mathrm{pH}$ lower than 4 . The volume was completed to the mark with $\mathrm{HCl} 0.01$ mol L-1. This solution was directly introduced in the flow system and analyzed with the batch turbidimetric procedure. Biodiesel: A sample of biodiesel was carefully calcinated at $550{ }^{\circ} \mathrm{C}$ similarly to the soy leaves procedure above described and the residue treated as done above for soy leaves.

\section{Results and Discussion}

In the FI reflectometric cell the LED and the LDR are relatively positioned in an angle of $90^{\circ}$ which vertex falls below the flow cell. This angle was chosen in order to minimize the specular reflection component and, at the same time, to maintain enough radiation reaching the detector.

When water or transparent solutions pass through the cell, the light coming from the light emitter diode (LED; $\lambda \max =566 \mathrm{~nm}$ ) partially reflects on the walls of the glass tube and on the solution interfaces. The reflection on the walls of the cell was minimized as it was constructed in black PTFE. The reflections on the glass walls and on the interfaces glass-solution and solutionglass still occur and are comparable to those in the cell constructed with white PTFE [1]. A constant part of this radiation reaches the detector (LDR; $\lambda \max =550 \mathrm{~nm}$ ) which resistance is then equilibrated in the Wheatstone bridge until the read voltage is zero. When the white precipitate of barium sulfate enters the cell, the radiation is randomly reflected on the particles in all directions. With the reflection process, the intensity of the light that reaches the detector changes upsetting the Wheatstone bridge. The resultant signal is registered, being proportional to the quantity of precipitate, in the working concentration range.

The so called diffuse reflectance process is currently considered when occurring on particles supported on solid surfaces. However, diffuse reflectance also occurs on solids dispersed in liquids and in gas phases. In figure 2 a simplified scheme of possible reflections of a light beam on suspended particles in a liquid, in a diffuse reflection process is shown. Obviously, main interaction between light and precipitate is expected to occur on the first layers of particles. The plausibility of this supposition increases with the increasing of the number of particles in the path of the light, i.e., 
with the increasing of the analyte concentration, reaching the maximum limit in the solid case.

Considering the configuration of the detection cell used in the present work these reflections occur on the suspended particles in the glass tube placed into the detection cell. The walls of the tube and the reflection and refraction on them and on interfaces are not shown in figure 2, for visual simplicity purposes.

Taking into account the geometry of the cell, the reflectance (radiation that is reflected out of the plane of incidence of the light) that occurs on the first rows of the suspended particles in the solution can be considered, in a whole, as a diffuse reflectance phenomenon.

\section{FIGURE 2}

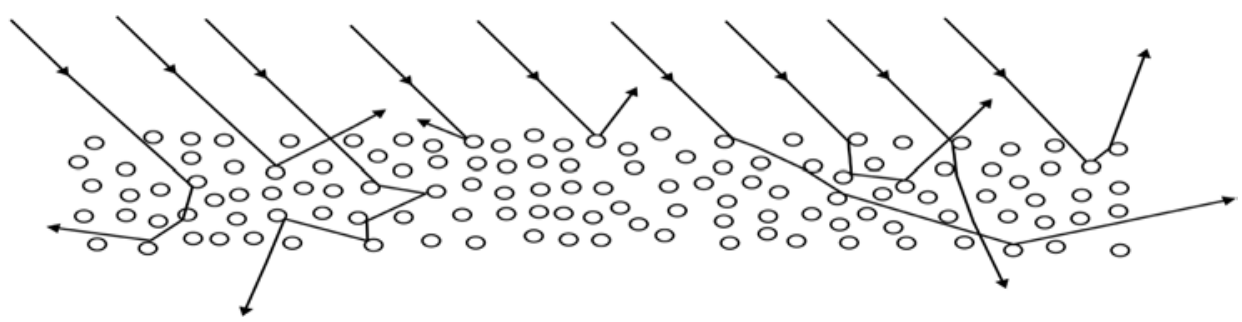

Figure 2. Simplified scheme representing some of the possible light reflections on solid particles suspended in a solution, in a diffuse reflection process.

To optimize the FI system, the influence of various parameters was investigated. The dependence of the signal height on the total flow rate

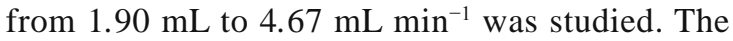
rate of $4.67 \mathrm{~mL} \mathrm{~min}^{-1}$ for the method was selected as it combines analytical signal of good intensity and high analytical frequency. The analytical signal was considered good when the obtained R.S.D. (i.e. the relation $100 \times$ S.D. / S; S.D. is the standard deviation and $\mathrm{S}$ is the analytical signal) was about $3 \%$ or better.

The influence of the reaction coil length was also investigated. It was observed that the signal increases when $\mathbf{L}$ increases from 50 to 100 $\mathrm{cm}$, falling beyond this length. The length of 100 cm was adopted.

The influence of the sampling volume on the analytical signal was studied from 200 to 500 $\mu \mathrm{L}$. After an initial fast increase, beyond $400 \mu \mathrm{L}$ a minor influence on the signal is observed. For the experiments the volume of $500 \mu \mathrm{L}$ was adopted as it furnishes a very good analytical signal without decreasing the analytical frequency.

Barium chloride solutions in presence of polyvinyl alcohol (PVA) 0.05\% w/v, in $\mathrm{HCl} 0.01$ mol L ${ }^{1}$, were prepared [25]. PVA acts as stabilizer of colloids increasing the repeatability of the system.

The influence of the concentration of ions $\mathrm{Ba}^{2+}$ on the analytical signal was studied and the results are shown in figure 3. Krug et al. [25] used a solution of $\mathrm{Ba}^{2+} 0.204 \mathrm{~mol} \mathrm{~L} \mathrm{~L}^{-1}$ for the quantitative precipitation of barium sulfate in a FI turbidimetric method. In the present work however it was observed that, above ca. $0.025 \mathrm{~mol} \mathrm{~L}^{-1}$ of $\mathrm{Ba}^{2+}$, the analytical signal does not present significant increase. To guarantee a safety margin of concentration for the quantitative precipitation of barium sulfate, a solution of barium chloride 0.05 mol L-1 was adopted. This decrease in the barium ions concentration means not only an economy of reagent but could also mean a decrease on the barium sulfate into the line along the operation time. 


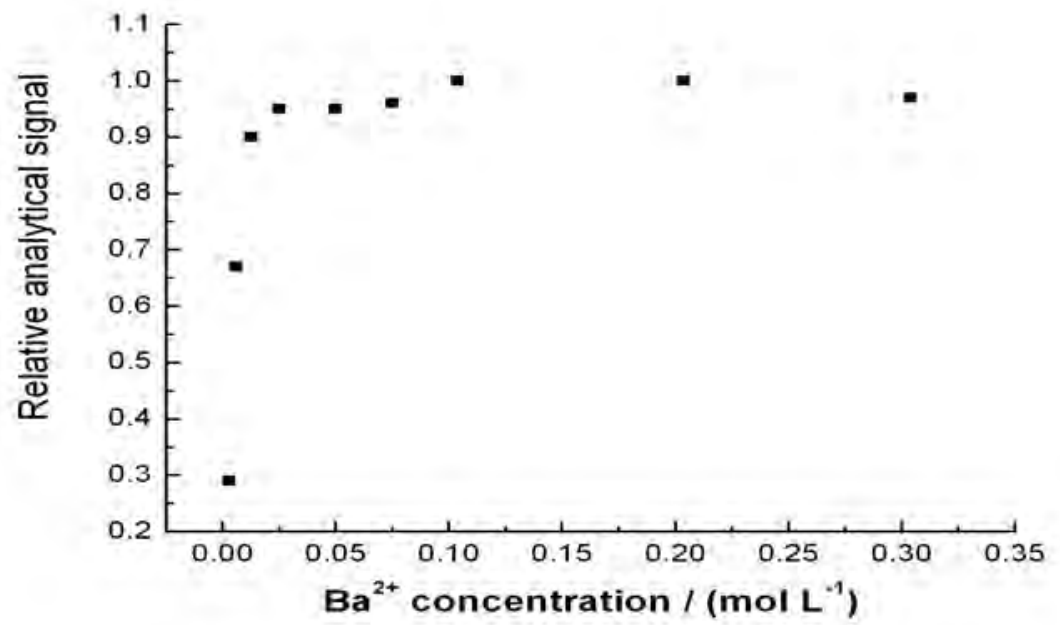

Figure 3. Influence of the concentration of ions $\mathrm{Ba}^{2+}$ on the height of the analytical signal. Concentration of sulfate ions $=100$ ppm; Flow rate $=4.67 \mathrm{~mL} \mathrm{~min}^{-1}$; Bobbin of reaction $=100 \mathrm{~cm}$; Sampling volume $=500$ $\mu L$.

To avoid accumulation of barium sulfate in the flow system, it periodically cleaned, after a set of five determinations, with an EDTA $0.06 \mathrm{~mol} \mathrm{~L}^{-1}$ in $\mathrm{NaOH} 0.2 \mathrm{~mol} \mathrm{~L}^{-1}$ solution, using a syringe $\mathbf{S}$ located before the mixer with magnetic agitation, as can be seen in figure 1 .

The calibration curve of the method was studied between 0 and 275 ppm. The linear beha-

vior is obeyed between 20 and 120 ppm and is described by the equation $\boldsymbol{h}=-1.138+0.0934$ $\boldsymbol{C}$, where $\boldsymbol{h}$ is the height of the signal in centimeters and $\boldsymbol{C}$ the concentration of sulfate in ppm (mg $\mathrm{L}^{-1}$ ). The correlation coefficient is $\mathrm{r}=0.9993$.

From 20 to 180 ppm the calibration curve is described by the polynomial equation $\boldsymbol{h}=-2.46$ $+0.144 C-3.05 \times 10^{-4} C^{2} \quad(\mathrm{r}=0.998)$.

Table 1. Comparison between values obtained by the proposed FI method and by the turbidimetric batch method, for different samples, using the statistical Student's $\boldsymbol{t}$-test and the $\boldsymbol{F}$ test [58] in 5\% significance level. In the biodiesel case, the results are expressed as \% w/w of sulfate; the soy leaves results are expressed as $\mathrm{mg}$ $\mathrm{kg}^{-1}$; waters analyses are expressed as $\mathrm{mg} \mathrm{L}^{-1}$ of sulfate.

\begin{tabular}{c|c|cc|c|cc|c|c|c} 
Sample & \multicolumn{1}{c}{ Label $^{\mathbf{a}}$} & \multicolumn{1}{c}{$\mathbf{F I}^{\mathbf{b}}$} & $\mathbf{\pm D P}$ & \multicolumn{1}{c}{$\mathbf{\pm D P R}$} & \multicolumn{1}{c}{ Turb $^{\mathbf{c}}$} & $\pm \mathbf{D P}$ & \multicolumn{1}{c}{$\pm \mathbf{D P R}$} & \multicolumn{1}{c}{$\boldsymbol{t}^{\mathbf{d}}$} & $\mathbf{F}^{\mathbf{e}}$ \\
\hline Water I & 20.6 & 22.3 & 0.7 & 3.3 & 23.2 & 0.7 & 3.0 & 1.36 & 1.00 \\
Water II & 20.6 & 24.1 & 0.4 & 1.8 & 25.6 & 0.7 & 2.7 & 3.34 & 3.06 \\
Water III & 42.0 & 67.4 & 2.6 & 3.9 & 70.1 & 2.2 & 3.1 & 1.52 & 1.40 \\
\hline & & & & & & & & & \\
\hline \hline Soy I & & 2.47 & 0.03 & 1.2 & 2.53 & 0.04 & 1.6 & 2.01 & 1.78 \\
Soy II & & 3.47 & 0.04 & 1.1 & 3.55 & 0.05 & 1.4 & 2.16 & 1.56 \\
\hline & & & & & & & & & \\
\hline Biodiesel & $0.003^{f}$ & 0.00158 & 0.00003 & 1.9 & 0.00155 & 0.00006 & 4.1 & 0.81 & 4.00 \\
\hline
\end{tabular}

${ }^{\mathbf{a}}$ Value declared in the label; ${ }^{\mathbf{b}} \mathbf{F I}=$ proposed flow injection method; ${ }^{\mathbf{c}} \mathbf{T u r b}=$ turbidimetric batch method; ${ }^{\mathbf{d}}$ calculated $\boldsymbol{t}$ value ; ${ }^{\mathbf{e}}$ calculated $\mathbf{F}$ value; ${ }^{\mathbf{f}}$ maximum limit allowed by legislation; for 5\% 
significance level: tabled $\mathbf{F}=6.94$; the number of determinations, $n_{1}$, for the flow method, was $n_{1}=5$; for the turbidimetric batch method $n_{2}=3$; tabled $\boldsymbol{t}$ is 2.45 .

In table 1 it can be observed that, excepting in the case of water II where the $\boldsymbol{t}$ calculated value is a little above the tabled value, all other results indicate agreement between the two methods in the $5 \%$ significance level. If the $1 \%$ significance level is considered, the tabled $\boldsymbol{t}=3.71$, and, therefore, even in the case of water II statistical agreement is observed [58].

\section{Conclusions}

In face of the above explained, the proposed FI reflectometric procedure for the determination of sulfate in various matrixes offers analytical quantitative results of good precision and accuracy; it is very simple to be performed; the instrumentation used is of relatively low cost; the reagent concentration is low; about 120 determinations can be easily performed per hour.

In comparison with the turbidimetric batch procedure the flow proposed method is more precise and simpler to be performed. In comparison with the flow turbidimetric method propo- sed by Krug et al. [25], the results are similar but the used reagent concentration in the method here proposed is lower; it also uses a commercial spectrophotometer whereas the here proposed procedure uses a home made detection device. Krug's method was applied to natural water samples and leaves digest. In the present work a new analytical matrix, biodiesel, was introduced presenting very good results.

Based on these results the method can be recommended as an alternative for the quantitative analysis of sulfate in a variety of samples.

\section{Acknowledgements}

The authors are grateful to CAPES, Coordenação de Aperfeiçoamento de Pessoal de Nível superior, to CNPq, Conselho Nacional de Pesquisa Científica e Tecnológica, and to FAPESP, Fundação de Amparo à Pesquisa do Estado de São Paulo, for the financial support.

Determinação Potenciométrica De Minoxidil Em Formulações Farmacêuticas De Uso Tópico

Received November 032008

Accepted October 142009

Resumo: Um método potenciométrico para a determinação de minoxidil em formulações farmacêuticas baseado na reação redox entre $\mathrm{K}_{2} \mathrm{Cr}_{2} \mathrm{O}_{7}$ e o minoxidil, foi desenvolvido. Os melhores resultados foram obtidos usando concentrações de $1,00 \times 10^{-2} \mathrm{~mol} \mathrm{~L}^{-1}$ para o minoxidil e $1,00 \times 10^{-3} \mathrm{~mol} \mathrm{~L}^{-1}$ para o $\mathrm{K}_{2} \mathrm{Cr}_{2} \mathrm{O}_{7}$ ambos diluídos em uma solução em de $\mathrm{H}_{2} \mathrm{SO}_{4} 2,00 \mathrm{~mol} \mathrm{~L}^{-1}$, a $60^{\circ} \mathrm{C}$. As recuperações para método proposto foram da ordem de $98,7 \%$ a $97,4 \%$ dependendo da amostra comercial. O método proposto foi aplicado à amostras comerciais contendo minoxidil e, quando comparado com resultados obtidos a partir de procedimentos cromatográficos, apresentou concordância no nível de confiança de 95\%, de acordo com o teste t-Student.

Palavras chave: Determinação minoxidil; titulação; potenciometria.

\section{References}

[1]. M. Tubino, C.A.R. Queiroz, Anal. Chim. Acta 600 (2007) 199.

[2]. F.A.A. Matias, M.M.D.C. Vila, M. Tubino, Sens. Actuators B Chem. 88 (2003) 60.

[3]. M.A. Gotardo, A.C. Gigante, H.R. Pezza, Talanta 64 (2004) 36.
[4]. A. Ghauch, C. Turnar, C. Fachinger, J. Rima, A. Charef, J. Suptil, M. Martin-Bouyer, Chemosphere 40 (2000) 1327.

[5]. A. Ghauch, J. Rima, A. Charef, J. Suptil, C. Fachinger, M. Martin-Bouyer, Talanta 48 (1999) 385.

[6]. M. Kompany-Zareh, M. Mansourian, F. Ravaee, Anal. Chim. Acta 471 (2002) (2002) 97.

[7]. I.A. Raimundo, R. Narayanaswamy, Sens. Actuators B Chem. 90 (SI) (2003)189.

[8]. M. Tubino, R.L. Souza, Talanta 68 (2006) 776. 
[9]. N. Malcik, P. Caglar, R. Narayanaswamy, Quim. Anal. 19 (Suppl. 1) (2000) 94.

[10]. J. Ruzicka, E.H. Hansen, Anal. Chim. Acta 173 (1985) 3.

[11]. I.P.A. Morais, I. V. Tóth, A. O. S. S. Rangel, Spectrosc. Lett. 39 (2006) 547.

[12]. G. Kortum, W. Brawn, G. Herzog, Angew. Chem. 2 (1963) 333.

[13]. J. Ruzicka, C.H. Pollema, K.M. Scudder, Anal. Chem. 65 (1993) 3566.

[14]. J. Ruzicka, Anal. Chim. Acta 308 (1995) 14.

[15]. B. Kuswandi, R. Narayanaswamy, Anal. Lett. (1998) 31 395.

[16]. R.H. Taylor, J.W. Grate, Talanta 42 (1995) 257.

[17]. M. Miró, W. Frenzel, J.M. Estela, V. Cerdà, Analyst 126 (2001) 1740.

[18]. M.I. Albero, J.A. Ortuno, M.S. Garcia, C. SanchezPedreño, R. Exposito, , J. Pharm. Biomed. Anal. 29 (2002) 779.

[19]. N.A. Yusof, M. Ahmad, Sens. Actuators B Chem. 94 (2003) 201.

[20]. C. Pons, R. Forteza, V. Cerdà, , Anal. Chim. Acta 528 (2005) 197.

[21]. L. Ferrer, G. Armas, M. Miró, J.M. Estela, V. Cerdà, Talanta 68 (2005) 343.

[22]. J.H. Lee, M.A. Han, S.W. Kang, S.S. Seo, H. Hwang, Bull. Korean Chem. Soc. 26 (2005) 36.

[23]. V. Kuban, Fresenius J.Anal. Chem. 346 (1993) 873.

[24]. S. M. B. Brienza, F. J. Krug, J. A. G. Neto, A. R. A. Nogueira, E. A. G. Zagatto, J. Flow Injection Anal. 10 (1993) 187.

[25]. F. J. Krug, H. Bergamin Filho, E. A. G. Zagatto, S. S. Jørgensen, Analyst 102 (1977) 503.

[26]. J. F. van Staden, W. D. Basson, Lab. Practice 29 (1980)1279.

[27]. S. Baban, D. Beetlestone, D. Betteridge, P. Sweet, Anal. Chim. Acta.114 (1980) 319.

[28]. W. D. Basson, J. F. van Staden, Water Res. 15 (1981) 333.

[29]. J. F. van Staden, Fresenius J. Anal. Chem. 310 (1982) 239.

[30]. J. F. van Staden, Fresenius J. Anal. Chem. 312 (1982) 438.

[31]. F. J. Krug, E. A. G. Zagatto, B. F. Reis, F. O. Bahia, A. O. Jacintho, S. S. Jørgensen, Anal. Chim. Acta. 145 (1983) 179 .

[32]. J. F. van Staden, Fresenius J. Anal. Chem. 326 (1987) 754.

[33]. A. B. Marsden, J. T. Tyson, Anal. Proc. 26 (1989) 157.

[34]. D. L. Heanes, Anal. Lett. 23 (1990) 543.

[35] D. L. Heanes, Anal. Lett. 23 (1990) 675.

[36]. K. Sonne, P. K. Dasgupta, Anal. Chem. 63 (1991) 427.

[37]. C. Morante, Anal. Chim. Acta. 249, 479 (1991).
[38]. M. M. Santos Filho, B. F. Reis, F. J. Krug, C. H. Collins, N. Baccan, Talanta 40 (1993) 1529.

[39]. S. M. B. Brienza, R. P. Sartini, J. A. G. Neto, E. A. G. Zagatto, Anal. Chim. Acta. 308 (1995) 269.

[40]. H. Liu, P. K. Dasgupta, Anal. Chim. Acta. 326 (1996) 13.

[41]. J. F. van Staden, R. E. Taljaard, Anal. Chim. Acta. 331 (1996) 271.

[42]. J. F. van Staden, R. E. Taljaard,. Fresenius J. Anal. Chem. 357 (1997) 577.

[43]. J. A. Vieira, B. F. Reis, E. A. M. Kronka, A. P. S. Paim, M. F. Giné, Anal. Chim. Acta. 366 (1998) 251.

[44]. R. A. S. Lapa, J. L. F. C. Lima, I. V. O. S. Pinto, Analusis 28 (2000) 295.

[45]. J. A. Vieira, I. M. Jr. Raimundo, B. F. Reis, Anal. Chim. Acta 438 (2001) 75.

[46]. I. P. A. Morais, A. O. S. S. Rangel, M. R. S. Souto, J. AOAC Int. 84 (2001) 59.

[47]. I. P. A. Morais, M. R. S. Souto, T. I. M. S. Lopes, A. O. S. S. Rangel, Water Res., 37 (2003) 4243.

[48]. H. R. Silva, M. A. Segundo, A. O. S. S. Rangel, J. Braz. Chem. Soc. 14 (2003) 59.

[49]. R. E. Santelli, P. R. S. Lopes, R. C. L. Santelli, A. L. R. Wagener, Anal. Chim. Acta. 300 (1995) 149.

[50]. J. Jakmunee, Y. Udnan, R. Morrison, R. Beckett, I. Mckinnon, K. Grudpan, Anal. Sci. 19 (2003) 1495.

[51]. M. Tubino, F.G. Barros, Quím. Nova 14 (1991) 49. [52]. J. Ruzicka, E.H. Hansen, Anal. Chim. Acta 114 (1980) 19.

[53]. T. C. Rodrigues, M. Tubino, O. E. S. Godinho, G. Oliveira Neto, Analytical Sciences, 17 (2001) 629.

[54]. M. Tubino, M. M. D. C. Vila, J. Flow Injection Anal. 23 (2006) 112.

[55]. M. Tubino, M. M. D. C. Vila, Ecl. Quím. 33 (2008) 67. [56]. O. A. Ohlweiler, Química Analítica Quantitativa, vol. 3, Livros Técnicos e Científicos, Rio de Janeiro, 1974, p. 723.

[57]. Official Methods of Analysis, 16th Ed., 3 $3^{\text {rd }}$ Suppl., AOAC International, Gaitherburg, MD, 1995, 973.57

[58]. K. Eckschlager, Errors Measurements and Results in Chemical Analysis, Van Nostrand Reinhold, London, 1972, p. 107. 